\title{
Imazapic interaction and mobility in soil cultivated with sugarcane in northeast Brazil
}

\section{Interação e mobilidade do Imazapic em solos cultivados com cana de açúcar no nordeste do Brasil}

\author{
Fernando Xavier de Assis ${ }^{1}$ (D), André Maciel Netto ${ }^{2}$ (D), Bruno Toríbio de Lima Xavier ${ }^{3}$ (D), Valmir Felix de Lima ${ }^{4}$ (D) $\&$ \\ João Paulo Siqueira da Silva² (D) \\ ${ }^{1}$ Universidade Federal Rural de Pernambuco, Recife, PE, Brasil \\ ${ }^{2}$ Universidade Federal de Pernambuco, Recife, PE, Brasil \\ ${ }^{3}$ União de Ensino do Sudoeste de Paraná, Francisco Beltrão, PR, Brasil \\ ${ }^{4}$ Instituto Nacional do Semiárido, Campina Grande, PB, Brasil \\ E-mails: xavierfernando7314@gmail.com (FXA), andre.netto@ufpe.br (AMN), bruno.toribio@unisep.edu.br (BTLX), \\ atrazina@gmail.com (VFL),joa.ouri@gmail.com (JPSS)
}

\begin{abstract}
In the plantation of sugarcane, Imazapic has used pre- or post-emergence, alone or in combination with other herbicides. When applied to the soil in pre-emergence, Imazapic can undergo the sorption, leaching and/or degradation processes due to physical, chemical and biological effects, besides being absorbed by weeds. The objective of this work was to evaluate the interaction and mobility of the Imazapic herbicide in the soil where the soil columns with a dystrophic Yellow Ultisol (YUd) and a dystrophic Red-Yellow Oxisol (RYOd) from northeastern Brazil were used. The higher adsorption potential of the RYOd is associated with higher clay content, higher $\mathrm{Fe}_{\mathrm{d}}$ and $\mathrm{Fe}_{\mathrm{o}}$ concentrations, and soil acidic $\mathrm{pH}$. The $\mathrm{CDE}-2$ sorption sites model adequately represented the experimental data from the Imazapic breakthrough curves to the RYOd and YUd soils. From the Kd partition coefficients for RYOd and YUd, high values of the GUS index (5.94 and 7.04, respectively) were calculated, confirming the high leaching potential of the Imazapic molecule in these soils.
\end{abstract}

Keywords: Soil columns; Contamination; Imazapic; Interaction and leaching.

\section{RESUMO}

Na plantação de cana-de-açúcar, o Imazapic tem sido usado em pré ou pós-emergência, isoladamente ou em combinação com outros herbicidas. Quando aplicado ao solo em pré-emergência, o Imazapic pode sofrer os processos de sorção, lixiviação e/ou degradação por efeitos físicos, químicos e biológicos, além de ser absorvido por plantas daninhas. O objetivo deste trabalho foi avaliar a interação e mobilidade do herbicida Imazapic no solo onde foram utilizadas colunas de solo com um Argissolo Amarelo distrófico (YUd) e um Latossolo Vermelho-Amarelo distrófico (RYOd) do Nordeste do Brasil. O maior potencial de adsorção do RYOd está associado ao maior teor de argila, maiores concentrações de $\mathrm{Fe}_{\mathrm{d}}$ e Fe e pH ácido do solo. O modelo CDE - 2 de dois sítios de sorção representou adequadamente os dados experimentais das curvas de eluição do Imazapic para os solos RYOd e YUd. A partir dos coeficientes de partição Kd para RYOd e YUd, altos valores do índice GUS (5,94 e 7,04, respectivamente) foram calculados, confirmando o alto potencial de lixiviação da molécula Imazapic nesses solos.

Palavras-chave: Colunas de solo; Contaminação; Imazapic; Interação e lixiviação. 


\section{INTRODUCTION}

In Brazil, the consumption of pesticides in sugarcane crops corresponds to approximately $13 \%$ of the total marketed. Some categories of pesticides are more commonly used than others, like herbicides. For example, the herbicides amount to $60 \%$ of the total pesticides marketed (Instituto Brasileiro de Geografia e Estatística, 2015). Imazapic is an herbicide belonging to the chemical group of imidazolinones, toxicological class II, of selective control applied in pre and/or post-emergence of plants in crops such as: Peanut (Arachis bypogaea L), Rice (Oryza sativa), Maize (Zea mays), Soybean (Glycine max) and Sugarcane (Saccharum offinarum) (Cox, 2003). Imazapic has a high solubility in water, and when dissolved it has a high contamination capacity of surface and groundwater, both evaluated by the EPA (American Environmental Protection Agency) criteria and by the GUS method (Gonçalves et al., 2013). There are studies on the leaching and volatilization of Imazapic in tropical soils in Brazil (Inoue et al., 2014; Monquero et al., 2010; Souza et al., 2020). However, studies already carried out are still not enough due to great diversity of soils, climatic, geographical and geological diversity.

In this context, one can understand the intimate relationship between soil and water and, the water table. Sandy soils allow a more efficient infiltration process; however, well-structured clayey soils or aggregates of better stability have a good infiltration rate (Haghnazari et al., 2015). The water infiltration rate in the soil, the process responsible for the recharge of the water table mainly reflects the physical attributes of the soil (Pan et al., 2018). Imazapic and Imazethapyr were detected in groundwater, as well as other pesticides such as Clomazone and Quinclorac (Silva et al., 2011).

Sorption is an interfacial process and refers to the attraction of one or more ionic or molecular layers to the surface and may be the mineral and/or organic phase of the soil. The sorption mechanism is fundamental in the dynamics of the advective-dispersive transport, persistence, transformation, and bioaccumulation of pesticides (Silva et al., 2011).

The solutes move in the soil through the water or through the mass flow. In contact with the soil, the pesticide can interact with the three phases that make up the porous medium, solid, liquid and gaseous fractions. The solid phase of the soil occupies about $50 \%$ of the soil volume, consisting of minerals and organic matter, while the other $50 \%$ consists of water and air, occupying 30 to 35\% and 15 to $20 \%$, respectively. Once in contact with the soil, the solute can be absorbed by plants or adsorbed by the soil or even undergo precipitation in a cyclic sequence of simultaneous physical and chemical processes (Meurer, 2012). The solid, liquid and gaseous fractions are susceptible to several exchange mechanisms involving macroscopic and microscopic scales (Milfont et al., 2008). Processes such as convection, advection, molecular diffusion, and hydrodynamic dispersion control the displacement of solutes and/or chemicals. Understanding these mechanisms is fundamental to predict the behavior of these pesticides in the various soil classes and thus mitigate possible harmful effects on the environment and its cultivation (Refatti et al., 2017).

The transport process is a highly nonlinear and space-time dynamic process for which models are still poorly validated at the larger scale. In addition, any experimental technique is operational at a certain scale, which is not necessarily the scale at which the process can reasonably be described, neither the scale at which a prediction is needed (Katagi, 2013).
A column of soil uniformly packed with sieved soil is generally more reproducible than using other techniques to assess the interaction and transport of pesticides. Many reliable laboratory leaching studies carried out on soil columns for various chemical classes of pesticides have been used to estimate the mobility potential of pesticides in the soil (Banzhaf \& Hebig, 2016; Guimarães et al., 2019; Milfont et al., 2008; Schreiber et al., 2018). Apart from the ability to effectively control the individual boundary conditions, the main advantage of column experiments compared to other experimental setups (such as those used in field experiments) is that conservative and reactive solute breakthrough curves can be derived, which represent the sum of the transport processes. Therefore, column experiments on the transport and eventual fate of pesticides under defined boundary conditions will always be important because the boundary conditions for field studies are poorly known, which affects the transferability of their results to other systems (Katagi, 2013; Vanclooster et al., 2006). However, the main objective of column experiments should not be specifically to achieve laboratory results that are transferable to field scale conditions, but to achieve an improved general understanding of the behavior of organic compounds, i.e., how different boundary conditions affect the behavior of the investigated compounds in natural environments. In this case, the boundary conditions of column experiments need to be known in order to ensure the correct interpretation of the results obtained (Banzhaf \& Hebig, 2016).

Therefore, the objective of this work is to assess the interaction and mobility of Imazapic by means of soil column assays in two distinct classes of soil in a sugarcane area in northeastern Brazil.

\section{MATERIAL AND METHODS}

\section{Imazapic}

Imazapic $\left(\mathrm{C}_{14} \mathrm{H}_{17} \mathrm{~N}_{3} \mathrm{O}_{3}\right)$ is an herbicide belonging to the chemical group of imidazolinones (Figure 1), toxicological class II, of selective control and applied in pre and/or post-emergence

\section{Imazapic}<smiles>CCC1(C)N=C(c2ncc(C)cc2C(=O)O)NC1=O</smiles>

( \pm )-2-[4,5-dihydro-4-methyl-4-(1methylethyl)-5-oxo-1H-imidazol-2-yl]-5methyl-3-pyridinecarboxylic acid

Figure 1. The molecular structure of Imazapic. 
of plants of various cultures. Imazapic is an herbicide of the dispersible granular type, acid character $(\mathrm{pKa}=3.9)$, used in the control of leaf-weed plants (Liliopsidas) and broadleaf (Magnoliopsida), and controls even difficult-to-control species such as Cyperus rotundus (Tiririca) and Cynodon sp. (Monquero et al., 2010; Ulbrich et al., 2005).

Its action is a result of the levels of three branched chains aliphatic amino acids valine, leucine, and isoleucine, by inhibiting hydroxyacetic acid synthetase, also known as acetolactate synthase enzyme (AHAS), a common enzyme in the biosynthetic pathway of these amino acids. Specifically, Imazapic inhibits the activity of the enzyme acetohydroxystease, that is a catalyst to produces amino acids required for protein synthesis and cell growth (International and Bureau of Land Management, 2005).

The half-life $\left(t_{1 / 2}\right)$ of about 120 days may be higher depending on the environmental conditions (Ulbrich et al., 2005) and the GUS $>4.0$ (batch) and $>6.0$ (columns) is an herbicide of high environmental risk due to potential contamination of groundwater and surface water.

Imazapic is an herbicide that can cause ecotoxicity to aquatic organisms, invertebrates, aquatic plants, living organisms in the soil and other terrestrial (non-mammalian) animals.

\section{Analysis of Imazapic}

Analysis of Imazapic were carried out at the Chemical Engineering Laboratory of the Federal University of Pernambuco (UFPE) by high-performance liquid chromatography (HPLC).

For this purpose, the analytical standard of the herbicide Imazapic was used, whose supplier, degree of purity and CAS (Chemical Abstracts Service) are shown in Table 1.

Therefore, from the stock solution of $250 \mathrm{mg} \mathrm{L}^{-1}$, working solutions were prepared in Acetonitrile and stored in weak amber at a temperature of $-18{ }^{\circ} \mathrm{C}$, used for the construction of the analytical curves on the HPLC.

From the dilutions with deionized water of the stock solution, solutions of the herbicide Imazapic were prepared with concentrations of 5, 10, 50, 100, 120, 150, 180 and $200 \mathrm{mg} \mathrm{L}^{-1}$.

The mobile phase used on the HPLC consisted of a mixture of acetonitrile:water $(60: 40, \mathrm{v} / \mathrm{v})$, acidified to $\mathrm{pH} 3.0$ with phosphoric acid $(1: 1, \mathrm{v} / \mathrm{v})$, the flow rate being of about $1.0 \mathrm{~mL} \mathrm{~min}^{-1}$. The maximum wavelength for detection was $212 \mathrm{~nm}$. The column used in the HPLC analyzes was the phenomenex $250 \times 6.60 \mathrm{~mm}$ of 5 microns.

\section{Soils}

Two types of soils were used in this work, a dystrophic Yellow Ultisol - half slope - (YUd, 747'59.02”S and 350'18.45”W)

Table 1. Imazapic standard of analysis.

\begin{tabular}{cc}
\hline \multicolumn{2}{c}{ Solid analytical standard } \\
\hline Herbicide & Imazapic \\
Supplier & Accustandard, Inc \\
Degree of purity & $99.5 \%$ \\
CAS & $104098-48-8$ \\
\hline
\end{tabular}

Source: Silva (2016) and a dystrophic Red-Yellow Oxisol - top - (RYOd, 7²4'28.61'S and $\left.35^{\circ} 131.10^{\prime \prime} \mathrm{W}\right)$. One can affirm that the soils of the region under study are deep, well drained and with a decrease of natural fertility due to weathering, hot and humid climate, thus forming very evolved soils. The climate is called rainy tropical with dry summer and annual average precipitation of $1.867 \mathrm{~mm}$. The vegetation is composed of Restinga Subperenifolia Forest.

Physical, chemical and mineralogical analysis were carried out and the residual content of the Imazapic herbicide was determined in the 0-20 cm layer, and then miscible displacement tests were carried out in columns of saturated soils.

The samples were randomly zigzagged in the area with 10 single samples in order to form a composite sample in the 0-20 cm layer and then taken to the Soil Contamination Assessment Laboratory (SCAL) of the Federal University of Pernambuco (UFPE) to carry out the necessary analysis. The samples were air-dried, de-routed and passed through a $2 \mathrm{~mm}$ mesh sieve to obtain Air Dried (AD), and then stored in plastic bags at an average temperature of $25{ }^{\circ} \mathrm{C}$. The granulometric analysis was performed by the densimeter method. The clay and silt fractions were determined by sedimentation after dispersion with sodium hexametaphosphate in a Wagner type agitator (Teixeira et al., 2017). The studied soils are of medium texture (YUd) and clayey (RYOd), the agricultural activity being sugarcane cultivated in the area for several years.

Chemical analyses were performed in the SCAL-UFPE and consisted in determining $\mathrm{pH}\left(\mathrm{H}_{2} \mathrm{O}\right.$ and $\left.\mathrm{KCl}\right)$, organic carbon, cation exchange capacity and oxides of $\mathrm{Fe}_{\mathrm{d}}$ (Iron Dithionite) and $\mathrm{Fe}_{\mathrm{o}}$ (Oxalate Iron). All the analyses were performed according to the Soil Analysis Methods Manual (Teixeira et al., 2017).

\section{Mineralogical analysis}

X-ray diffraction (XRD) analysis on clay samples mounted in the form of powdered (metal support) and oriented (glass support) was carried out on a Shimadzu XRD 6100 equipment of the Laboratory of Crystallochemistry and Micromorphology at the Academic Unit of Garanhuns (AUG/UFRPE). The clay was previously macerated in an agate mortar and the XRD spectra were obtained in the following configuration: $1^{\text {st }}$ min velocity (20); amplitude from 5 to $50^{\circ}$ (20); Cu radiation $\mathrm{K} \alpha$ at $30 \mathrm{kV}$ and $30 \mathrm{~mA}$ and with a graphite monochromator. The glass-mounted samples were submitted to pre-treatment of iron oxides by sodium dithionite-citrate-bicarbonate (DCB) (Mehra \& Jackson, 2013) and saturation with Potassium $\left(\mathrm{K}^{+}\right)$, for later acquisition of the spectra at temperatures of 25,350 and $500{ }^{\circ} \mathrm{C}$ (Jackson, 2005).

\section{Determination of soil organic carbon}

Organic Carbon was determined by the modified Walkley \& Black method (Walkley \& Black, 1934) based on oxidation of the organic matter via humidification using potassium dichromate $\left(\mathrm{K}_{2} \mathrm{Cr}_{2} \mathrm{O}_{7}\right)$ dried in an oven at $105^{\circ} \mathrm{C}$ and dissolved in the sulfuric medium, by using like a heat source the heat removed from the hot plate heating. After oxidation, all the excess dichromate was 
titrated with ammoniacal ferrous sulfate $\left.\left(\mathrm{Fe} \mathrm{NH}_{4}\right)_{2}\left(\mathrm{SO}_{4}\right)_{2} \cdot 6 \mathrm{H}_{2} \mathrm{O}\right)$ at $0.1 \mathrm{~mol} \mathrm{~L}^{-1}$.

\section{The experimental procedure in soil columns}

The tests to characterize the hydrodynamic and hydrodispersive properties were performed in a single flow for each soil, defined from the value of the saturated hydraulic conductivity.

Glass columns with dimensions of $20.5 \mathrm{~cm}$ in height and $5 \mathrm{~cm}$ in diameter were used. The soil conditioning in the columns was performed in approximately $5 \mathrm{~cm}$ layers lightly compacted, then the columns were saturated using an electrolytic solution to $2 \mathrm{mmol} \mathrm{L}^{-1}$ of $\mathrm{CaCl}_{2}$, next to the soil solution, so that the soil colloids were not destabilized, compromising permeability due to the decrease in ionic strength (Roy \& Dzombak, 1996).

The feeding of the columns of each soil with the displacement solution was performed by using a peristaltic pump (ISMATEC, twelve channels) connected at the top of the column, the effluents of the solutions being collected at the base of each column through a fraction collector (SPECTRUM CF-2) (Figure 2). Prior to the Imazapic molecule assays, $\mathrm{KBr}$ (tracer) assays were performed. After complete saturation at the column, two pore volumes of the electrolytic solution $\left(\mathrm{CaCl}_{2}\right)$ and one pore volume of $\mathrm{KBr}$ were applied in a steady state downward flow regime. The flow rate defined according to saturated hydraulic conductivity values for each soil was calculated from the average of the first 10 volumes collected after the electrolyte solution was applied. The effluent solutions of $\mathrm{KBr}$ were determined in a conductivity meter.

For the tests with Imazapic (in commercial form, Plateau, in the presence of $70 \%$ a.i.), the pulse application was 1 pore volume in the concentration of $737 \mathrm{mg} \mathrm{L}^{-1}$, average concentration applied in both soils. Feeding of the soil columns with the solution containing the Imazapic (Plateau) was carried out in a downward steady state flow regime (Figure 2). The tests consisted essentially of moving a known volume of liquid $V_{0}$ in the soil column, by means of a solution containing the Imazapic in the concentration of $C_{0}$, at a mean apparent velocity $v$. The solute diffuses at the same time as it infiltrates at variable speeds through the soil pores. The displacement of the solute feed is followed by measuring the concentration $C$ of the effluent over time. The evolution of the $C / C_{0}$ ratio as a function of the number of pore volumes $\left(V / V_{0}\right)$ of the collected effluent provides the solute advancement curve (commonly referred to as BTC - Breakthrough curve).

\section{Convective-Dispersion Equation (CDE)}

The convective-dispersion equation (CDE) (Coats \& Smith, 1964) was used to determine the transport parameters of solutes in a porous medium. For the particular condition of an undisturbed porous medium with a continuous flow of water, the one-dimensional equation that describes the transport of a solute is presented as:

$R \frac{\partial c}{\partial t}=D \frac{\partial^{2} C}{\partial Z^{2}}-v \frac{\partial c}{\partial t}$

where, $C$ is the mass of solute per volume of solution $\left[\mathrm{M} \mathrm{L}^{-3}\right]$; $D$ is the coefficient of hydrodynamic dispersion $\left[\mathrm{L}^{2} \mathrm{~T}^{-1}\right] ; v$ is the mean water velocity in the pores $(v=q / \theta$, q is the Darcy flow density); $z$ is the spatial coordinate $[\mathrm{L}]$; $t$ is the time $[\mathrm{T}]$; and $R$ is the retardation factor given by:

$R=1+\frac{\rho_{d} K_{d}}{\theta}$

$K_{d}\left[\mathrm{M} \mathrm{L}^{-3}\right]$ is the linear distribution coefficient $\left(K_{d}=\mathrm{S} / \mathrm{C}\right)$, representing the concentrations distributed between the liquid phase $(C)$ and the adsorbed phase $(S) ; \theta$ is the volumetric water content $\left[\mathrm{L}^{3} \mathrm{~L}^{-3}\right]$, and $\varrho_{d}$ is the bulk density $\left[\mathrm{M} \mathrm{L}^{-3}\right]$.

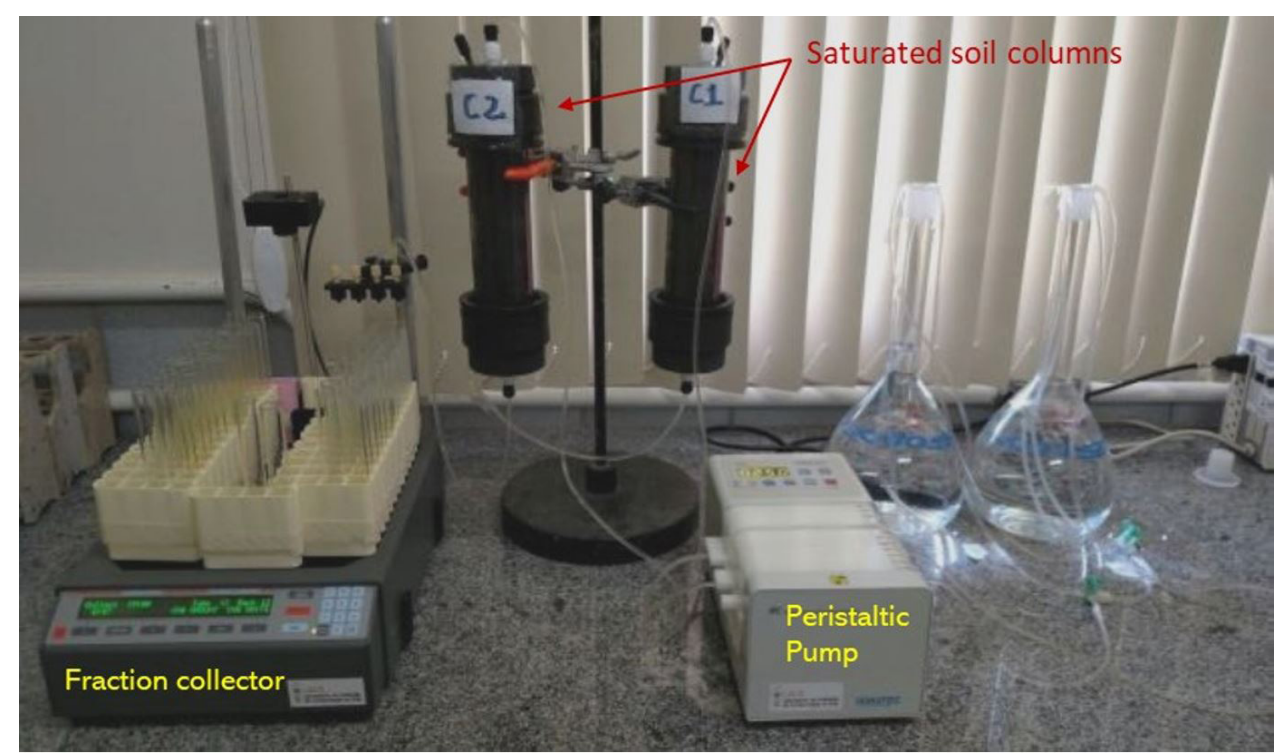

Figure 2. Experimental assay of solute transport in saturated soil columns. C1 = dystrophic Yellow Ultisol, and C2 = dystrophic Red-Yellow Oxisol. Source: the Author. 


\section{Model CDE-2 sorption sites}

The chemical non-equilibrium model makes a distinction between a type-1 (equilibrium) and type-2 (first-order kinetic) adsorption sites (Cameron \& Klute, 1977; Selim et al., 1976). In its dimensionless form, the model representing chemical nonequilibrium at two sorption sites is given by:

$\beta R \frac{\partial C_{1}}{\partial T}+(1-\beta) R \frac{\partial C_{2}}{\partial T}=\frac{1}{P} \frac{\partial^{2} C_{1}}{\partial Z^{2}}-\frac{\partial C_{1}}{\partial Z}$

$(1-\beta) R \frac{\partial C_{2}}{\partial T}=\omega\left(C_{1}-C_{2}\right)$

where $\beta$ is the partitioning coefficient, $T$ is the dimensionless time; $Z$ dimensionless spatial coordinate; $C_{1}$ and $C_{2}$ concentrations in the fraction of the sites in equilibrium and non-equilibrium, respectively, $R$ the retardation factor; $\omega$ is the dimensionless mass transfer coefficient (Damköler number); $P$ is the Peclet number. For the two sorption sites model, $\beta$ and $\omega$ are defined as:

$\beta=\frac{\theta+f \rho_{d} K_{d}}{\theta+\rho_{d} K_{d}}$

$\omega=\frac{\alpha(1-\beta) R L}{v}$

where $f$ is the fraction of exchange sites that are always at equilibrium; $\alpha\left[\mathrm{T}^{-1}\right]$ is the first-order kinetic rate coefficient; $L[\mathrm{~L}]$ is the length of the column; $\theta\left[\mathrm{L}^{3} \mathrm{~L}^{-3}\right]$ is the volumetric water content; and $v\left[\mathrm{~L} \mathrm{~T}^{-1}\right]$ is the average water velocity in the pores.

The boundary conditions for (1), (3) and (4) are: Initial condition:

$C_{l}(Z, 0)=C_{2}(Z, 0)=0$

Upper and lower boundary conditions, respectively:

$C_{1}(0, T)=\left\{\begin{array}{c}1 \text { for } 0<T<T_{0} \\ 0 \text { for } T>T_{0}\end{array}\right.$

$\frac{\partial C_{1}}{\partial Z}(\infty, T)=\frac{\partial C_{2}}{\partial Z}(\infty, T)=O$

The hydrodispersive parameters, $R$ and $D$, were obtained by fitting the CDE model to the experimental breakthrough curves of the $\mathrm{Br}$ tracer, while the $\mathrm{R}, D, \beta$ and $\omega$ parameters of the CDE-2S model were obtained from the fitting to the Imazapic breakthrough curves by means of the program CXTFIT
(STANMOD, Simunek et al., 1999). The distribution coefficient is given by the normalized partition for the organic matter content and is represented by:

$K_{O C}=\frac{K_{d}}{f_{O C}} 100$

where $f_{O C}\left(\mathrm{dag} \mathrm{kg}^{-1}\right)$ indicates the organic carbon fraction of the soil.

\section{Groundwater Ubiquity Score (GUS)}

To estimate Imazapic leaching, the GUS index proposed by Gustafson (1989) was used. The GUS index represents a non-dimensional empirical index based on the $K o c$ value $\left(\mathrm{L} \mathrm{kg}^{-1}\right)$ and the half-life time $t_{1 / 2}$ (days). When the GUS index $<1.8$ the herbicide is considered non-leachable, while indices greater than 2.8 are considered leachable, and values between 1.8 and 2.8 are of intermediate behavior. The GUS index is defined by the following equation:

$G U S=\log t_{1 / 2}\left(4-\log K_{O C}\right)$

\section{RESULTS AND DISCUSSION}

\section{Soil physical attributes}

According to the values of the physical attributes (Table 2), there is a predominance of the sand fraction in the superficial layer $(0-20 \mathrm{~cm})$ of the dystrophic Red-Yellow Oxisol (RYOd) and the dystrophic Yellow Ultisol (YUd), presenting 486 and $854 \mathrm{~g} \mathrm{~kg}^{-1}$, respectively, and the coarse sand is higher than the fine sand content, mainly in the YUd. The predominance of total sand on the other fractions and the relationship between total sand and fine sand infers on the resistance of the material of origin to the physical and chemical weathering agents, even in climatic conditions that favor this phenomenon. The low clay content and the high sand content in the $0-20 \mathrm{~cm}$ surface layer in the YUd denotes a more incipient development of the soil, which may be related to the mineralogical composition of the source material, with a predominance of more minerals resistant as quartz.

The determination of the textural class of the RYOd was sandy clay loam and the YUd was loamy sand. Soil texture directly affects the adsorption potential of pesticides, especially pre-emergence herbicides that are applied directly to the soil surface. Soils with sandy texture favor the higher Imazapic leaching

Table 2. Physical and chemical characterization of dystrophic Yellow Ultisol (YUd) and dystrophic Red-Yellow Oxisol (RYOd) samples.

\begin{tabular}{|c|c|c|c|c|c|c|c|c|c|}
\hline \multirow{4}{*}{ Soil } & \multirow{3}{*}{ Sand } & \multirow{3}{*}{ Loam } & \multirow{3}{*}{ Clay } & \multirow{3}{*}{ OC } & \multicolumn{2}{|c|}{ Iron oxides } & \multirow{4}{*}{ CEC } & \multirow{3}{*}{$\begin{array}{c}\mathrm{pH} \\
\mathrm{H}_{2} \mathrm{O}\end{array}$} & \multirow{3}{*}{$\begin{array}{c}\mathrm{pH} \\
\mathrm{KCl}\end{array}$} \\
\hline & & & & & $\mathrm{Fe}_{\mathrm{d}}$ & $\mathrm{Fe}_{\mathrm{o}}$ & & & \\
\hline & & & & & (DCB) & (Oxa) & & & \\
\hline & \multicolumn{6}{|c|}{---------------------------g kg-1------------------------ } & & ---- & --- \\
\hline YUd & 854 & 43 & 103 & 16 & 5.056 & 4.703 & 4.3 & 7.0 & 5.7 \\
\hline RYOd & 486 & 214 & 300 & 16 & 17.414 & 7.521 & 7.2 & 5.1 & 4.2 \\
\hline
\end{tabular}

$\mathrm{OC}=$ Organic Carbon; $\mathrm{CEC}=$ Cation exchange capacity; $\mathrm{Fe}_{\mathrm{d}}=$ Iron Dithionite; $\mathrm{Fe}_{\mathrm{o}}=$ Oxalate Iron. 
in the soil, the clay minerals and the organic matter affected the adsorption of the molecule (Castro Neto et al., 2017). Firmino et al. (2008) observed higher leaching of Imazapyr in soils with sandy texture in relation to the clayey soil. It was observed leaching of the Imazapyr, after simulation of rain of $40 \mathrm{~mm} \mathrm{~h}^{-1}$ (Souza et al., 1999), and when used in soil columns (Bundt et al., 2014).

\section{Soil chemical attributes}

The highest iron oxide $\left(\mathrm{Fe}_{\mathrm{d}}\right.$ and $\mathrm{Fe}$ ) was observed in RYOd (Table 2), which favors a higher adsorption potential with RYOd. The iron oxides can alter the chemical capacity of the soil, because they have variable charge, being able to adsorb anions and cations, participating in the retention of pollutants (Meurer, 2012). On studying the Imazaquim, the same chemical group of Imazapic, Regitano et al. (1997) observed an expressive relationship between the adsorption of Imazaquim and positive charges of $\mathrm{Fe}$ and $\mathrm{Al}$ oxides surfaces due to the mechanisms of binder exchange and/or binder formation. The presence of oxides of amorphous $\mathrm{Fe}$ and organic matter at $\mathrm{pH}<5$ are strongly effective in the retention of Imazapyr, even in the chemical group of Imazapic (Monquero et al., 2010; Pusino et al., 1997).

The higher levels of iron oxides, CEC and soil acidic $\mathrm{pH}$ of RYOd favor a higher adsorption by Imazapic in relation to YUd (Table 1). In an experimental study of adsorption with Imazapic, that is a weak acid, high adsorption rates were found in soils with high levels of oxides, CEC and organic matter (Aichele \& Penner, 2005; Pusino et al., 1997). The herbicide group of imidazolinones is strongly influenced by soil pH. Aichele \& Penner (2005) observed high correlation of adsorption in soils with $\mathrm{pH} 5.0$ as compared to soils with $\mathrm{pH}$ 7.0. In studies conducted in areas cultivated with rice in Rio Grande do Sul, it was observed that predominantly low soil $\mathrm{pH}$ values favor the adsorption of these herbicides (Oliveira et al., 2004; Schreiber et al., 2017). For this reason, leaching and potential contamination of groundwater can occur when Imazapic and other herbicides of the imidazolinones group are applied to alkaline soils and/or certain agroclimatic zones (Cessna et al., 2012; Souza et al., 2016).

\section{Mineralogical attributes}

According to the results of X-ray diffraction (XRD) analysis of the clay fraction, the soils present mineralogical uniformity
(Figure 3). The clay fraction of YUd and RYOd consists mainly of kaolinite, quartz, goethite and dolomite. These minerals are common in well drained soils and are located in hot and humid climate and favor the formation of very weathered soils (monosialitization processes). The clay minerals such as kaolinite (1:1, non-expansive) may not exert a great influence on the adsorption of Imazapic, since they have attraction charges that can be generated in their edges by the dissociation of $\mathrm{H}^{+}$protons, thus facilitating the adsorption of cationic herbicides (Loux et al., 1989; Oliveira \& Regitano, 2009; Oliveira \& Brighenti, 2011; Silva et al., 2007; Weber, 1980), differently from the case of Plateau (with $70 \%$ of Imazapic), which is an acidic herbicide.

\section{Interaction of Imazapic with soil}

The defined and determined parameters used in soil miscible displacement tests for the hydrodispersive characterization of soils using the $\mathrm{KBr}$ as tracer are shown in Table 3. The tests were performed at flow rates of 0.324 and $0.245 \mathrm{~cm}^{3} \mathrm{~min}^{-1}$ for the RYOd and or YUd, respectively.

The parameters obtained by the CDE fitting with the $\mathrm{KBr}$ are presented in Table 4 . The retardation factor $(R)$ values for the tracer used $(\mathrm{Br}-)$ were close to unit (1.0) for the two replicates of the RYOd and for the replicate 2 (R2) of the YUd. However, the value of $R$ for the replicate 1 (R1) of YUd was 0.85 . The value of the retardation factor less than unity for non-reactive solutes (tracers) has been reported in several studies (Gaudet et al., 1977; Kamra et al., 2001; Schulin et al., 1987; Veeh et al., 1994) to indicate negative adsorption $(\mathrm{Kd}<0)$. This phenomenon can be explained by the fact that there has been anionic exclusion (Schulin et al., 1987) or due to immobile water regions that do not participate in solute transport (Gaudet et al., 1977; Lennartz \& Meyer-Windel, 1995; Seyfried \& Rao, 1987).

The CDE model adequately described the breakthrough curves of the $\mathrm{KBr}$ assays, with determination coefficients above 0.98 (Table 4). Nkedi-Kizza et al. (1989) stated that in studies of miscible displacement using deformed samples, physical nonequilibrium has not been verified due to the destruction of the soil structure by soil disruption and sieving. Therefore, considering the good quality in the fitting of the KBr breakthrough curves and homogeneity of the values of the parameters estimated using the $\mathrm{CDE}$ model, it is possible to disregard the absence of the behavior

Table 3. Parameters determined experimentally for the miscible displacement of the KBr tracer in the dystrophic Yellow Ultisol (YUd) and the dystrophic Red-Yellow Oxisol (RYOd).

\begin{tabular}{|c|c|c|c|c|c|c|}
\hline 20 & $\varrho_{s}$ & $V p$ & $\theta_{s}$ & $q$ & $\boldsymbol{V}$ & $T_{\text {pulse }}$ \\
\hline $\mathrm{cm}$ & $\mathrm{g} \mathrm{cm}^{-3}$ & $\mathrm{~cm}^{3}$ & $\mathrm{~cm}^{3} \mathrm{~cm}^{-3}$ & $\mathrm{~cm} \mathrm{~h}^{-1}$ & $\mathrm{~cm} \mathrm{~h}^{-1}$ & $\mathbf{h}$ \\
\hline \multicolumn{7}{|c|}{ dystrophic Yellow Ultisol } \\
\hline R1 & 1.58 & 151.15 & 0.375 & 0.761 & 2.03 & 10.1 \\
\hline $\mathbf{R} 2$ & 1.61 & 146.36 & 0.364 & 0.724 & 1.99 & 10.3 \\
\hline \multicolumn{7}{|c|}{ dystrophic Red-Yellow Oxisol } \\
\hline $\mathbf{R} 1$ & 1.49 & 163.42 & 0.411 & 1.04 & 2.53 & 8.0 \\
\hline $\mathbf{R} 2$ & 1.46 & 168.25 & 0.423 & 1.13 & 2.67 & 7.6 \\
\hline
\end{tabular}

$\varrho_{\mathrm{s}}=$ soil bulk density; $V_{p}=$ pore volumes; $\theta_{s}=$ saturated volumetric water content; $q=$ flow density; $v=\mathrm{q} / \theta_{\mathrm{s}}=$ average pore water velocity; and $T_{\text {pulse }}=$ pulse application time. 
Table 4. Hydrodispersive parameters obtained by the CDE fitting from the miscible displacement tests of the KBr (tracer) solution.

\begin{tabular}{|c|c|c|c|c|c|c|}
\hline $0-20$ & $D^{\S}$ & $R^{\S}$ & $\mathbf{r}^{2}$ & $\lambda$ & $P$ & $K_{d}$ \\
\hline $\mathrm{cm}$ & $\mathrm{cm}^{2} \mathrm{~h}^{-1}$ & - & - & $\mathrm{cm}$ & - & $\mathrm{g} \mathrm{kg}^{-1}$ \\
\hline \multicolumn{7}{|c|}{ dystrophic Yellow Ultisol } \\
\hline R1 & $1.365 \pm 0.300$ & $0.85 \pm 0.002$ & 0.998 & 0.672 & 30.5 & 0.000 \\
\hline $\mathbf{R} 2$ & $0.831 \pm 0.060$ & $1.07 \pm 0.005$ & 0.981 & 0.392 & 52.3 & 0.016 \\
\hline \multicolumn{7}{|c|}{ dystrophic Red-Yellow Oxisol } \\
\hline R1 & $0.410 \pm 0.032$ & $1.04 \pm 0.004$ & 0.981 & 0.213 & 96.2 & 0.011 \\
\hline $\mathbf{R} 2$ & $0.970 \pm 0.060$ & $1.02 \pm 0.004$ & 0.989 & 0.406 & 50.5 & 0.005 \\
\hline
\end{tabular}

$s(\bar{x} \pm s)=$ mean \pm mean squared error.
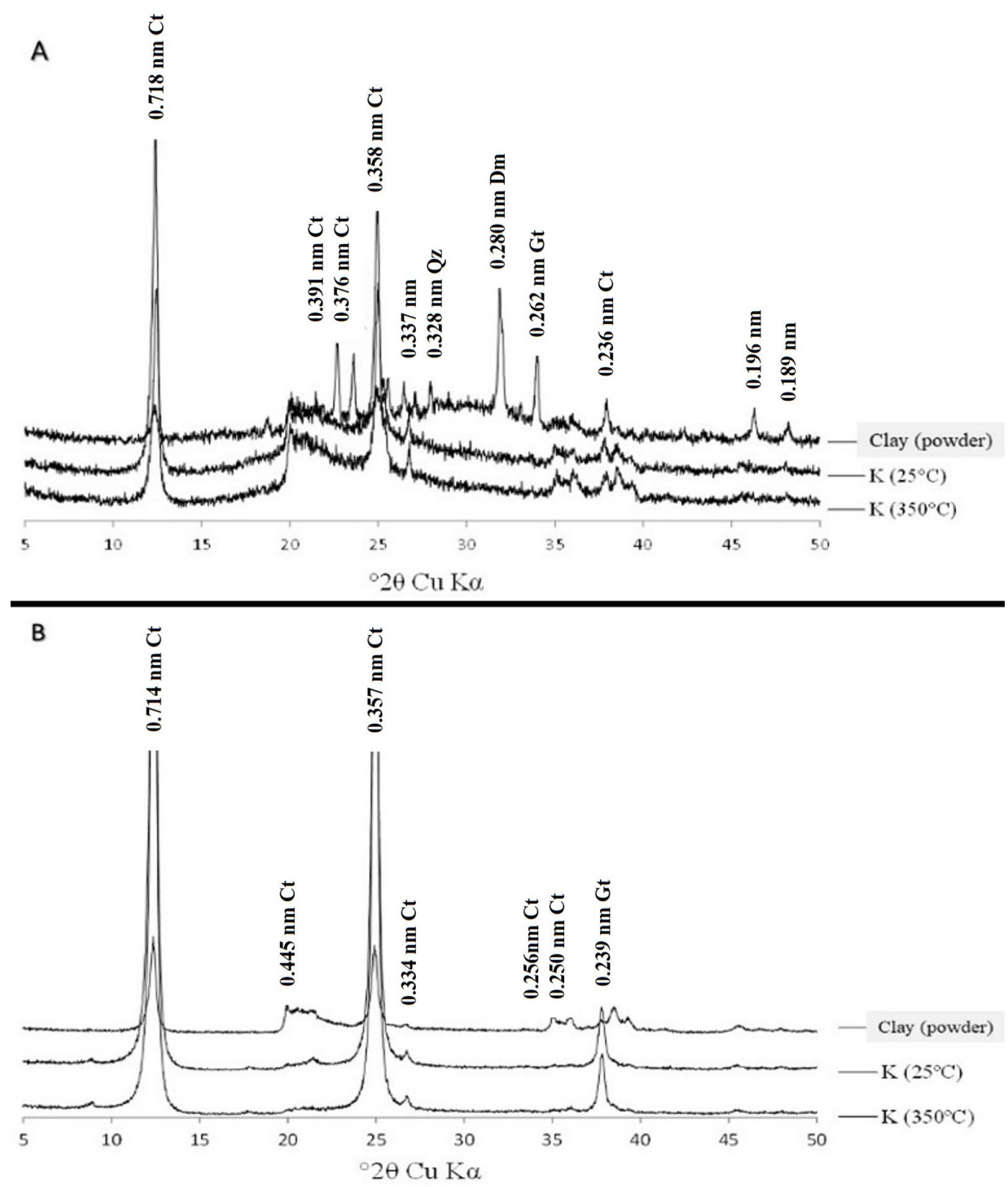

Figure 3. X-ray diffractograms of the clay fraction of (A) YUd and (B) RYOd of the 0-20 cm layer. (Ct-kaolinite; Qz-quartz; Dm-dolomite; Gt-goethite).

of two regions of mobile and immobile water (non-equilibrium physical) for both soils. In this case, the parameters obtained with the CDE model are enough to describe the hydrodispersive behavior of the studied soils.
The hydrodynamic dispersion coefficient $(D)$ ranged from 0.41 to 1.36 in the two studied soils (Table 4), the highest average being for YUd $\left(1.098 \mathrm{~cm}^{2} \mathrm{~h}^{-1}\right)$ than for RYOd $\left(0.694 \mathrm{~cm}^{2} \mathrm{~h}^{-1}\right)$. The Peclet number shows that the predominant process in all 
trials was convection ( $P>10$, Yong et al., 2012) with values higher than 30. The hydrodynamic dispersion coefficient, responsible for the dispersion of the solute in the porous matrix, is due to two phenomena, molecular diffusion and mechanical dispersion. Since the process is predominantly due to mechanical dispersion (convection), the highest average value obtained for YUd is due to the greater distribution of pore sizes for the $\mathrm{YUd}$, resulting in a higher velocity distribution for this soil, and, consequently, a higher value for the hydrodynamic dispersion coefficient.

The calculated values of the partition coefficient $\left(K_{d}\right)$ were close to zero for $\mathrm{KBr}$ (tracer), indicating almost non-interaction, this low interaction is what is expected of a good tracer.

The hydrodispersive parameters obtained by the CDE model - two sorption sites for RYOd and YUd are shown in Table 5.

The values of the hydrodynamic dispersion coefficient $(D)$ were higher for the miscible displacement tests of the Imazapic solution for RYOd. The dispersivity $(\lambda=D / \nu)$ was lower for the loam sand YUd layer and higher for the sandy clay loam RYOd layer. The mean value of the dispersivity for RYOd is four times higher than that calculated for YUd. According to Javaux et al. (2006), the dispersivity depends on the flow conditions and is not constant in the porous medium. According to Bunsri et al. (2008) and Fashi (2015), the loam soil has a greater dispersivity than the sandy soil and therefore $\lambda$ is larger due to the finer texture, which corroborates with the results found in this work. The hydrodynamic dispersion coefficient is one of the most sensitive parameters for the errors of measurement of the fractions of collected concentrations, as well as the variation in velocity distribution of water in pores (Le Renard et al., 1977).
The values of retardation factor $(R)$ for the YUd and RYOd ranged from 1.23 to 1.35 and 1.75 to 1.94 , respectively, thus indicating that the YUd had a slightly smaller interaction than RYOd. In addition to the retardation factor, the shapes of the asymmetric for both breakthrough curves show the chemical non-equilibrium sorption due to two sites (equilibrium and another following a first-order of kinetic desorption). Other authors also found similar behavior of the chemical non-equilibrium in other herbicides in the same group of imidazolinones (Barizon et al., 2006; Porfiri et al., 2015). The Peclet number (P), greater in YUd, indicates the predominance of the convective process $(P>10)$ while in RYOd, the predominant process was dispersive $(P<10)$, where there was slow kinetics and increased Imazapic interaction with the soil. Comparing with the breakthrough curve for the tracer (Figure 4A), the behavior of the breakthrough curve for YUd (Figure 5A) was almost identical, exhibiting a slight kinetic behavior in the time dependent desorption process. As for RYOd, this behavior is very clear, and is well represented by a first-order kinetic of desorption.

The parameter $\beta$ represents the partition coefficient, that is, the fraction of solute that participates in the adsorption process in instantaneous equilibrium. In this case, the participation of Imazapic in the interaction in instantaneous equilibrium was higher in average values in the YUd than in the RYOd. This behavior is associated with the lower content of clay and oxides of $\mathrm{Fe}_{\mathrm{d}}$ and $\mathrm{Fe}_{\mathrm{o}}$ and higher $\mathrm{pH}(7.0)$ in $\mathrm{YUd}$ and were determinant physico-chemical factors in the molecule/soil interaction. According to Monquero et al. (2010), herbicides of the group of imidazolinones with predominance of anionic charges are repelled

Table 5. Hydrodispersive parameters obtained by the fitting CDE - two sorption sites from the miscible displacement tests of the Imazapic solution.

\begin{tabular}{|c|c|c|c|c|c|c|c|}
\hline $0-20$ & $D^{\mathbb{S}}$ & $R^{\mathbb{S}}$ & $\beta \$$ & $\omega^{\mathbb{S}}$ & $\mathbf{r}^{2}$ & $\lambda$ & $P$ \\
\hline $\mathrm{cm}$ & $\mathrm{cm}^{2} \mathrm{~h}^{-1}$ & - & - & - & - & $\mathrm{cm}$ & - \\
\hline \multicolumn{8}{|c|}{ dystrophic Yellow Ultisol } \\
\hline $\mathbf{R} 1$ & $1.14 \pm 0.11$ & $1.35 \pm 0.23$ & $0.748 \pm 0.011$ & $2.12 \mathrm{E}-2 \pm 1.8 \mathrm{E}-3$ & 0.996 & 0.564 & 36.42 \\
\hline $\mathbf{R} 2$ & $2.33 \pm 0.11$ & $1.23 \pm 0.93$ & $0.998 \pm 0.753$ & $2.27 \mathrm{E}-5 \pm 8.3 \mathrm{E}-4$ & 0.995 & 1.170 & 17.52 \\
\hline \multicolumn{8}{|c|}{ dystrophic Red-Yellow Oxisol } \\
\hline $\mathbf{R} 1$ & $6.92 \pm 2.03$ & $1.75 \pm 0.11$ & $0.658 \pm 0.087$ & $3.76 \mathrm{E}-2 \pm 0.015$ & 0.979 & 2.734 & 7.5 \\
\hline
\end{tabular}

$s(\bar{x} \pm s):$ mean \pm mean squared error.
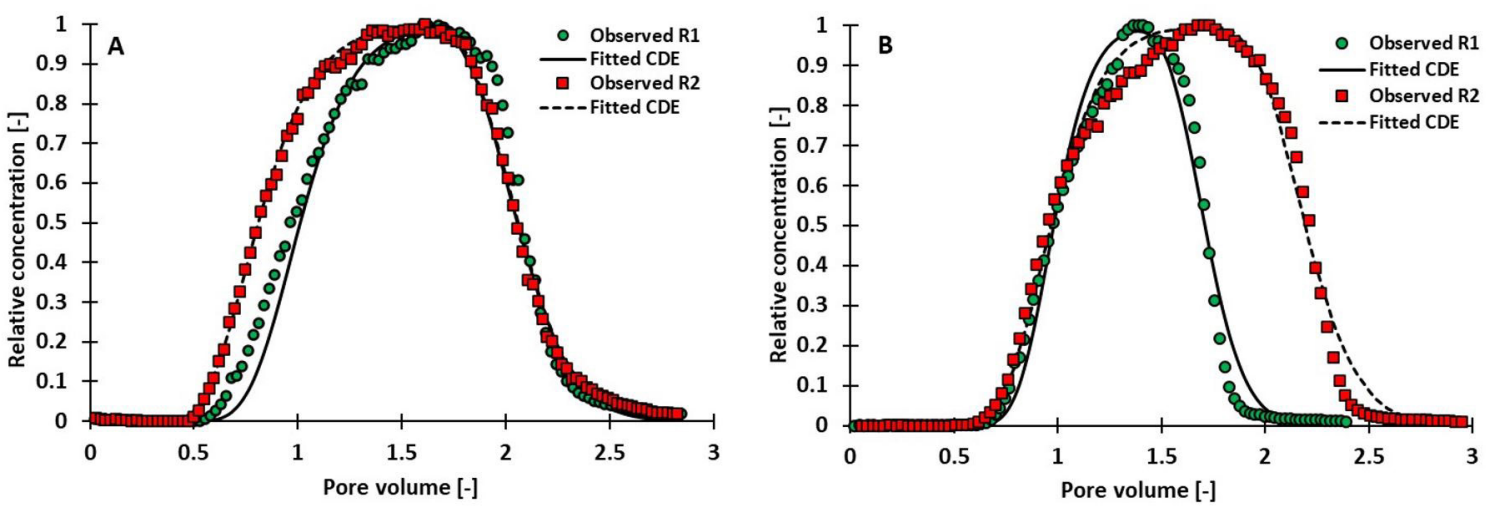

Figure 4. Experimental and fitted KBr breakthrough curves with CDE model for (A) dystrophic Yellow Ultisol (YUd); and (B) dystrophic Red-Yellow Oxisol (RYOd). 

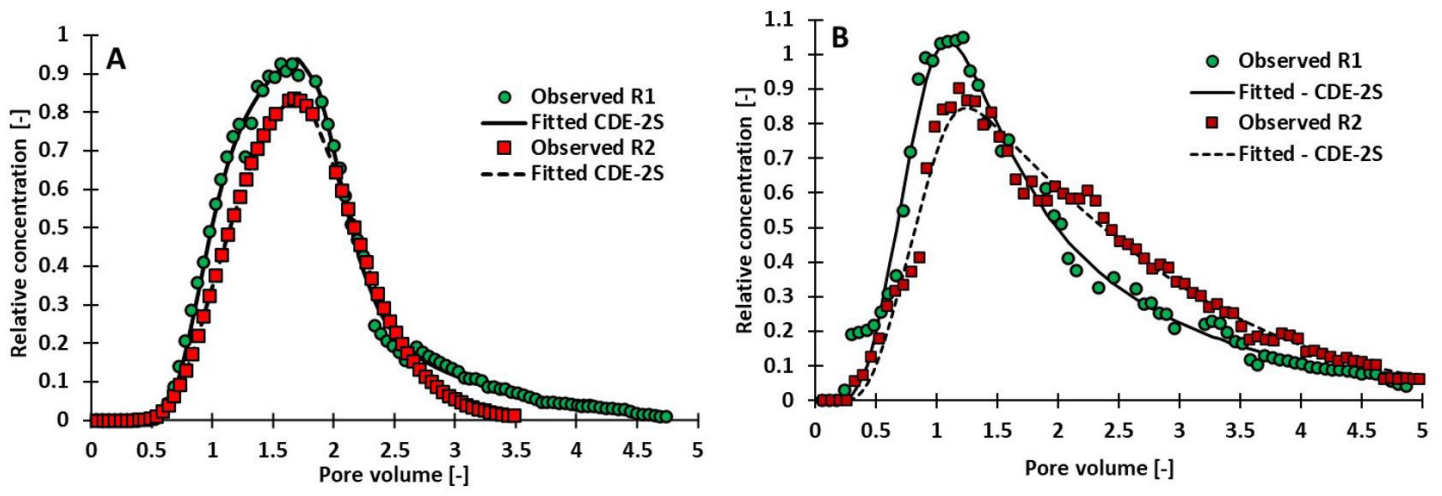

Figure 5. Breakthrough curves (experimental and fitted) from Imazapic to: (A) dystrophic Yellow Ultisol (YUd); and (B) dystrophic Red-Yellow Oxisol (RYOd).

Table 6. Hydrodispersive parameters calculated from the parameters obtained by fitting the CDE-2 sorption sites model to the data from the Imazapic miscible displacement tests for the dystrophic Red-Yellow Oxisol and the dystrophic Yellow Ultisol.

\begin{tabular}{|c|c|c|c|c|}
\hline $0-20$ & $\alpha$ & $\mathbf{K}_{\mathrm{d}}$ & $f$ & $(1-f)$ \\
\hline $\mathrm{cm}$ & $\mathbf{h}^{-1}$ & $\mathrm{~L} \mathrm{~kg}^{-1}$ & -- & -- \\
\hline \multicolumn{5}{|c|}{ dystrophic Yellow Ultisol } \\
\hline R1 & $6.18 \mathrm{E}-3$ & 0.083 & 0.027 & 0.973 \\
\hline $\mathrm{R} 2$ & $1.05 \mathrm{E}-3$ & 0.052 & 0.991 & 0.009 \\
\hline \multicolumn{5}{|c|}{ dystrophic Red-Yellow Oxisol } \\
\hline R1 & $7.75 \mathrm{E}-3$ & 0.197 & 0.203 & 0.797 \\
\hline $\mathrm{R} 2$ & $1.24 \mathrm{E}-2$ & 0.252 & 0.001 & 0.999 \\
\hline
\end{tabular}

by the negative charges of the mineral and organic colloids of the soil when situated at $\mathrm{pH} 7.0 \pm 2.0$. According to the authors, in situations with soil at pH 6.0 the Imazapic will be quite dissociated and the adsorption mechanism should be exclusively ionic in order to occur a significant adsorption.

The calculated values of $K_{d}$ had variations of 0.052 to 0.083 and 0.19 to $0.25 \mathrm{~L} \mathrm{~kg}^{-1}$ in YUd and RYOd, respectively, as shown in Table 6 . The mass transfer coefficient $(\alpha)$ increased with the increase of the degree of chemical non-equilibrium in the sorption (1-f). According to Gaber et al. (1995), high values of $\alpha$ indicate the presence of slow sorption kinetics. The mass transfer coefficient $(\alpha)$ was higher for the RYOd, where there was an increase in the chemical non-equilibrium conditions of the sorption. The parameter $f$ corresponds to sorption sites in equilibrium and indicates the degree of chemical non-equilibrium in the sorption.

The breakthrough curves, experimental and fitted with the CDE - 2 sorption sites are presented in Figure 5, YUd (A) and RYOd (B). The level of interaction between the Imazapic molecule and the soil is evaluated according to the value of the retardation factor, the higher the value of the retardation factor the greater the interaction. The asymmetric shape of the breakthrough curves, due to the prolongation of the descending part of the curves, can be attributed to the kinetic desorption process, and the ascending part of the curves, adsorption phase, refers to the linear isotherm processes. Asymmetric behavior was more evident in RYOd than in YUd.
The initial part of the breakthrough curve is mainly due to interaction with soil organic matter, which is weak and reversible, and where equilibrium is rapidly established. The descending phase of the curve corresponds to the very slow desorption due to the interactions with the iron oxide, whose binding is stronger, and the equilibrium is established more slowly, as observed for RYOd, which had a great interaction with Imazapic.

Imazapic has higher interaction with organic matter $(\mathrm{OM})$. However, the values of Total Carbon (OC) are the same for the $0-20 \mathrm{~cm}$ layers for both soils (Table 2). The organic matter in the two soils favors the hydrophobic interactions more than the electrostatic interactions between the soil colloids (Spark \& Swift, 2002). Thus, the main physical and chemical attributes of the soil evaluated in the Imazapic adsorption process were iron $\left(\mathrm{Fe}_{\mathrm{d}}\right.$ and $\mathrm{Fe}_{\mathrm{o}}$ ) oxides and clay content, higher in RYOd.

\section{Kd, Koc coefficients and GUS index}

As observed in Table 6, the calculated $K_{o c}$ values for YUd ranged from 5.2 to $5.3\left(\mathrm{~L} \mathrm{~kg}^{-1}\right)$, whereas for RYOd the variation was 12.3 to $15.7\left(\mathrm{~L} \mathrm{~kg}^{-1}\right)$. This difference in $K$ values is associated to the high content of clay and iron oxides in the RYOd, the main factors that influenced the Imazapic adsorption difference between the soils, since the $O C$ content and the mineralogical characteristics were identical for the two studied soils.

Some parameters are used as potential indicators of leaching of pesticide molecules such as $K_{d} K_{o c}$ and GUS index. The GUS 
Table 7. Partition coefficient values $\left(K_{d}\right.$ and $\left.K_{o}\right)$ and GUS index.

\begin{tabular}{|c|c|c|c|c|}
\hline $0-20$ & Soil texture & $K_{d}$ & $K_{o c}$ & GUS \\
\hline $\mathrm{cm}$ & ---- & $\mathrm{L} \mathrm{kg}^{-1}$ & $\mathrm{~L} \mathrm{~kg}^{-1}$ & ---- \\
\hline \multicolumn{5}{|c|}{ dystrophic Yellow Ultisol } \\
\hline $\mathbf{R} 1$ & LS & 0.083 & 5.2 & 6.83 \\
\hline $\mathbf{R} 2$ & LS & 0.052 & 5.3 & 7.25 \\
\hline \multicolumn{5}{|c|}{ dystrophic Red-Yellow Oxisol } \\
\hline $\mathbf{R} 1$ & SCL & 0.197 & 12.3 & 6.05 \\
\hline $\mathbf{R} 2$ & SCL & 0.252 & 15.7 & 5.83 \\
\hline
\end{tabular}

$K_{d}=$ Coefficient of partition; $K_{o c}=$ Standardized adsorption coefficient for organic matter content; GUS = Gustafson Index (Gustafson, 1989 ); LS = Loamy Sand; SCL $=$ Sandy Clay Loam.

index is calculated from the values of $K_{o c}$ (Equation 8) and the half-life time, shown in Table 7. The GUS index for Imazapic was higher than 2.8 and was included in the category of leachable products according to the criteria proposed by (Gustafson, 1989). The indexes obtained for the YUd are slightly higher. However, the two soils presented high values of the GUS index, thus reinforcing the concern about the use of these products.

The marked mobility of Imazapic in the two studied soils indicates that the use of the Imazapic must be used consciously, obeying all the technical requirements of the product. Their transfer to subsurface layers may increase the persistence of these herbicides in the soil, thus making it less susceptible to microbiological degradation processes.

The transfer of the Imazapic from the surface layer to the subsurface layer increases its persistence in the environment, especially in the case of Oxisol soils, because they are more weathered. So, they are more clayey and with lower OM content, resulting in less microbial activity. The results of the half-life studies conducted by Marinho et al. (2018) showed that these herbicides are moderately persistent with both Imazethapyr and Imazapic and is more persistent in RYOd.

\section{CONCLUSIONS}

The present study concerned to characterize the interaction and the transport of the herbicide Imazapic, with dystrophic Yellow Ultisol (YUd) and a dystrophic Red-Yellow Oxisol (RYOd) from northeastern Brazil.

As mineralogical attributes of the studied soils, the presence of kaolinite was not the main aspect in the adsorption of Imazapic to the soils. The higher adsorption potential of the dystrophic Red-Yellow Oxisol (RYOd) is associated with higher clay content, higher $\mathrm{Fe}_{\mathrm{d}}$ and $\mathrm{Fe}_{\mathrm{o}}$ concentrations, and soil acidic $\mathrm{pH}$.

The CDE model applied to the transport of the $\mathrm{KBr}$ (tracer) discarded the possibility of physical non-equilibrium (absence of the behavior of two regions of mobile and immobile water), thus enabling the analysis of Imazapic transport by the CDE - 2 sorption sites model for both soils. Thus, the CDE 2 sorption sites model adequately represented the experimental data from the Imazapic breakthrough curves to the RYOd and YUd soils.

The chemical non-equilibrium in the transport of Imazapic occurs in both soils, being much more evident in the RYOd in the Imazapic desorption process.
Comparison of the breakthrough curves of $\mathrm{KBr}$ (tracer) and Imazapic showed a slightly retardation of Imazapic during transport, evidencing a fast leaching due to the low sorption, that is, low values of the partition coefficients, to both studied soils (YUd and RYOd). As expected, Imazapic was weakly adsorbed in these two soils, presenting a potential risk of groundwater contamination of the region.

\section{REFERENCES}

Aichele, T. M., \& Penner, D. (2005). Adsorption, desorption, and degradation of imidazolinones in soil. Weed Technology, 19(1), 154159. http://dx.doi.org/10.1614/WT-04-057R.

Banzhaf, S., \& Hebig, K. H. (2016). Use of column experiments to investigate the fate of organic micropollutants: a review. Hydrology and Earth System Sciences, 20(9), 3719-3737. http://dx.doi. org/10.5194/hess-20-3719-2016.

Barizon, R. R. M., Lavorenti, A., Regitano, J. B., Prata, F., \& Tornisielo, V. L. (2006). Simulação do transporte e da sorção de imazaquin em colunas de solo. Revista Brasileira de Ciência do Solo, 30(4), 615-623. http://dx.doi.org/10.1590/S0100-06832006000400002.

Bundt, A. D. C., Avila, L. A., Agostinetto, D., Refatti, J. P., Cassol, L., \& Rockemback, F. C. (2014). Lixiviação de imidazolinonas em resposta a diferentes manejos de irrigação em solo de cultivo de arroz irrigado. Ciência Rural, 44(11), 1943-1949. http://dx.doi. org/10.1590/0103-8478cr20131216.

Bunsri, T., Sivakumar, M., \& Hagare, D. (2008). Numerical modelling of tracer transport in unsaturated porous media. Journal of Applied Fluid Mechanics, 1(1), 62-70.

Cameron, D. R., \& Klute, A. (1977). Convective-dispersive solute transport with a combined equilibrium and kinetic adsorption model. Water Resources Research, 13(1), 183-188. http://dx.doi. org/10.1029/WR013i001p00183.

Castro Neto, M. D., Souza, M. F., Silva, D. V., Faria, A. T., Silva, A. A., Pereira, G. A. M., \& Freitas, M. A. M. (2017). Leaching of imidazolinones in soils under a clearfield system. Archives of Agronomy and Soil Science, 63(7), 897-906. http://dx.doi.org/10.1 080/03650340.2016.1249471. 
Cessna, A. J., Elliott, J. A., \& Bailey, J. (2012). Leaching of three imidazolinone herbicides during sprinkler irrigation. Journal of Environmental Quality, 41(3), 882-892. PMid:22565269. http:// dx.doi.org/10.2134/jeq2011.0198.

Coats, K. H., \& Smith, B. D. (1964). Dead-end pore volume and dispersion in porous media. Society of Petroleum Engineers Journal, 4(01), 73-84. http://dx.doi.org/10.2118/647-PA.

Cox, C. (2003). Imazapic. Journal of Pesticide Reform, 23(3), 10-14.

Fashi, F. H. (2015). A review of solute transport modeling in soils and hydrodynamic dispersivity. Agricultura, 95(4), 134-142. http:/ / dx.doi.org/10.15835/arspa.v95i3-4.11791.

Firmino, L. E., Tuffi Santos, L. D., Ferreira, F. A., Ferreira, L. R., \& Tiburcio, R. A. S. (2008). Sorção do imazapyr em solos com diferentes texturas. Planta Daninha, 26(2), 395-402. http:/ /dx.doi. org/10.1590/S0100-83582008000200016.

Gaber, H. M., Inskeep, W. P., Comfort, S. D., \& Wraith, J. M. (1995). Nonequilibrium transport of atrazine through large intact soil cores. Soil Science Society of America Journal, 59(1), 60-67. http:// dx.doi.org/10.2136/sssaj1995.03615995005900010009x.

Gaudet, J. P., Jégat, H., Vachaud, G., \& Wierenga, P. J. (1977). Solute transfer, with exchange between mobile and stagnant water, through unsaturated sand. Soil Science Society of America Journal, 41(4), 665. http://dx.doi.org/10.2136/sssaj1977.03615995004100040009x.

Gonçalves, M. S., Bettin, J. P., Silva Junior, L. C. S., Sampaio, S. C., \& Dal Bosco, T. C. (2013). Adequação dos modelos de Langmuir e Freundlich na adsorção de cobre em solo argilosso do sul do Brasil. HOLOS, 4, 37. http://dx.doi.org/10.15628/holos.2013.1458.

Guimarães, A. C. D., Mendes, K. F., Campion, T. F., Christoffoleti, P. J., \& Tornisielo, V. L. (2019). Leaching of herbicides commonly applied to sugarcane in five agricultural soils. Planta Daninha, 37, e019181505. http://dx.doi.org/10.1590/s0100-83582019370100029.

Gustafson, D. I. (1989). Groundwater ubiquity score: a simple method for assessing pesticide leachability. Environmental Toxicology and Chemistry, 8(4), 339-357. http://dx.doi.org/10.1002/etc.5620080411.

Haghnazari, F., Shahgholi, H., \& Feizi, M. (2015). Factors affecting the infiltration of agricultural soils. Factors Affecting the Infiltration of Agricultural Soils: Review, 6(5), 21-35.

Inoue, M. H., Possamai, A. C. S., Mendes, K. F., Ben, R., de Matos, A. K. A., \& dos Santos, E. G. (2014). Potencial de lixiviação de herbicidas utilizados na canade-açúcar em solos contrastantes. Bioscience Journal, 30(5), 659-665.

Instituto Brasileiro de Geografia e Estatística - IBGE. (2015). Indicadores de desenvolvimento sustentável: Brasil: 2015. IBGE, Coordenação de Recursos Naturais e Estudos Ambientais (352 p.). Rio de Janeiro. Retrieved in 2021, January 15, from https:/ / biblioteca.ibge.gov. br/visualizacao/livros/liv94254.pdf
International and Bureau of Land Management. ENSR International. (2005). Reno, Nevada Imazapic ecological risk assessment: final report. Utah: Utah State University. Retrieved in 2021, January 15, from https://digitalcommons.usu.edu/govdocs/539

Jackson, M. L. (2005). Soil chemical analysis: advance course (29th ed. Madison: UW-Madison Libraries Parallel Press.

Javaux, M., Vanderborght, J., Kasteel, R., \& Vanclooster, M. (2006). Three-dimensional modeling of the scale- and flow rate-dependency of dispersion in a heterogeneous unsaturated sandy monolith. Vadose Zone Journal, 5(2), 515-528. http://dx.doi. org/10.2136/vzj2005.0056.

Kamra, S., Lennartz, B., Van Genuchten, M. T., \& Widmoser, P. (2001). Evaluating non-equilibrium solute transport in small soil columns. Journal of Contaminant Hydrology, 48(3-4), 189-212. PMid:11285931. http://dx.doi.org/10.1016/S0169-7722(00)00156-X.

Katagi, T. (2013). Soil column leaching of pesticides. In D. M. Whitacre (Ed.), Reviews of environmental contamination and toxicology (pp. 1-105). New York: Springer. https://doi.org/10.1007/9781-4614-4448-0_1.

Le Renard, J., Calvet, R., Tournier, C., \& Hubert, A. (1977). Mesure du coefficient de dispersion hydrodynamique longitudinal dans un milieu poreux saturé. Annales Agronomiques, 28(1), 47-64.

Lennartz, B., \& Meyer-Windel, S. (1995). The role of immobile water in unsaturated substrates. Hydrogéologie, 4, 75-83.

Loux, M. M., Liebl, R. A., \& Slife, F. W. (1989). Adsorption of clomazone on soils, sediments, and clays. Weed Science, 37(3), 440444. http://dx.doi.org/10.1017/S0043174500072192.

Marinho, M. I. C., Souza, W. M., Cabral, M. F., Castro Neto, M. D., Queiroz, M. E. L. R., \& Silva, A. A. (2018). Sorption-desorption behavior of imazethapyr and imazapic on six Brazilian soils. Planta Daninha, 36, e018177486. http://dx.doi.org/10.1590/ s0100-83582018360100140.

Mehra, O. P., \& Jackson, M. L. (2013). Iron oxide removal from soils and clays by a dithionite-citrate system buffered with sodium bicarbonate. In E. Ingerson (Ed.), Clays and clay minerals (pp. 317327). London: Pergamon. . http://dx.doi.org/10.1016/B978-008-009235-5.50026-7.

Meurer, E. J. (2012). Fundamentos de química do solo (4. ed.). Porto Alegre: Evangraf.

Milfont, M. L., Antonino, A. C. D., Martins, J. M. F., Netto, A. M., Gouveia, E. R., \& Correa, M. M. (2008). Paclobutrazol transport in soil columns. Revista Brasileira de Ciência do Solo, 32(5), 2165-2175. http://dx.doi.org/10.1590/S0100-06832008000500037.

Monquero, P. A., Silva, P. V., Silva Hirata, A. C., Tablas, D. C., \& Orzari, I. (2010). Lixiviação e persistência dos herbicidas 
sulfentrazone e imazapic. Planta Daninha, 28(1), 185-195. http:/ / dx.doi.org/10.1590/S0100-83582010000100022.

Nkedi-Kizza, P., Brusseau, M. L., Rao, P. S. C., \& Hornsby, A. G. (1989). Nonequilibrium sorption during displacement of hydrophobic organic chemicals and calcium-45 through soil columns with aqueous and mixed solvents. Environmental Science \& Technology, 23(7), 814-820. http://dx.doi.org/10.1021/es00065a009.

Oliveira, J. R. R., \& Regitano, J. (2009). Dinâmica de pesticidas no solo. In V. Melo \& L. Alleoni (Eds.), Química e mineralogia do solo (pp. 187-248). Viçosa: Sociedade Brasileira de Ciência do Solo.

Oliveira, M. F., \& Brighenti, A. M. (2011). Comportamento dos herbicidas no ambiente. In R. S. Oliveira Júnior, J. Constantin, M. H. Inoue (Ed.). Biologia e manejo de plantas daninhas. Curitiba: Omnipax.

Oliveira, M. F., Colonna, I., Prates, H. T., Mantovani, E. C., Gomide, R. L., \& Oliveira Júnior, R. S. (2004). Sorção do herbicida imazaquin em Latossolo sob plantio direto e convencional. Pesquisa Agropecuária Brasileira, 39(8), 787-793. http://dx.doi.org/10.1590/ S0100-204X2004000800009.

Pan, R., Martinez, A., Brito, T., \& Seidel, E. (2018). Processes of soil infiltration and water retention and strategies to increase their capacity. Journal of Experimental Agriculture International, 20(2), 1-14. http://dx.doi.org/10.9734/JEAI/2018/39132.

Porfiri, C., Montoya, J. C., Koskinen, W. C., \& Azcarate, M. P. (2015). Adsorption and transport of imazapyr through intact soil columns taken from two soils under two tillage systems. Geoderma, 251-252,1-9. http://dx.doi.org/10.1016/j.geoderma.2015.03.016.

Pusino, A., Petretto, S., \& Gessa, C. (1997). Adsorption and desorption of Imazapyr by Soil. Journal of Agricultural and Food Chemistry, 45(3), 1012-1016. http://dx.doi.org/10.1021/jf960214t.

Refatti, J. P., Avila, L. A., Noldin, J. A., Pacheco, I., \& Pestana, R. R. (2017). Leaching and residual activity of imidazolinone herbicides in lowland soils. Ciência Rural, 47(5), 1-6. http:/ / dx.doi. org/10.1590/0103-8478cr20160705.

Regitano, J. B., Bischoff, M., Lee, L. S., Reichert, J. M., \& Turco, R. F. (1997). Retention of imazaquin in soil. Environmental Toxicology and Chemistry, 16(3), 397-404. http://dx.doi.org/10.1002/ etc. 5620160302 .

Roy, S. B., \& Dzombak, D. A. (1996). Colloid release and transport processes in natural and model porous media. Colloids and Surfaces. A, Physicochemical and Engineering Aspects, 107, 245-262. http:// dx.doi.org/10.1016/0927-7757(95)03367-X.

Schreiber, F., Scherner, A., Andres, A., Concenço, G., Ceolin, W. C., \& Martins, M. B. (2018). Experimental methods to evaluate herbicides behavior in soil. Revista Brasileira de Herbicidas, 17(1), 71. http://dx.doi.org/10.7824/rbh.v17i1.540.
Schreiber, F., Scherner, A., Massey, J. H., Zanella, R., \& Avila, L. A. (2017). Dissipation of Clomazone, Imazapyr, and Imazapic herbicides in paddy water under two rice flood management regimes. Weed Technology, 31(2), 330-340. http://dx.doi.org/10.1017/wet.2017.5.

Schulin, R., Wierenga, P., Fluhler, H., \& Leuenberger, J. (1987). Solute transport a stony soil. Soil Science Society of America Journal, 51(1), 36-42. http://dx.doi.org/10.2136/sssaj1987.0361599500 $5100010007 x$.

Selim, H., Davidson, J., \& Mansell, R. (1976). Evaluation of a twosite adsorption-desorption model for describing solute transport in soils. Summer Computer Simulation Conference, (1976), 444-448.

Seyfried, M. S., \& Rao, P. S. C. (1987). Solute transport in undisturbed columns of an aggregated tropical soil: preferential flow effects. Soil Science Society of America Journal, 51(6), 1434-1444. http:/ /dx.doi. org/10.2136/sssaj1987.03615995005100060008x.

Silva, A., Vivian, R., \& Oliveira, J. R. R. (2007). Herbicides: soil behavior. In A. Silva \& F. Silva (Eds.), Weed management topics (pp. 189-248). Viçosa: Universida.

Silva, D. R. O., Avila, L. A., Agostinetto, D., Bundt, A. D. C., Primel, E. G., \& Caldas, S. S. (2011). Ocorrência de agrotóxicos em águas subterrâneas de áreas adjacentes a lavouras de arroz irrigado. Quimica Nova, 34(5), 748-752. http://dx.doi.org/10.1590/ S0100-40422011000500004.

Silva, F. X. da. (2016). Interação físico-química do herbicida imazapic em solos cultivados com cana de açúcar na mata norte de Pernambuco. (Dissertação de mestrado). Universidade Federal de Pernambuco, Recife. Retrieved from https:/ / repositorio.ufpe.br/ bitstream/123456789/19636/1/Disserta\%C3\%A7\%C3\%A3o\%20 FXavier\%20FINAL\%20\%28Biblioteca\%29.pdf.

Simunek, J., van Genuchten, Mt., Sejna, M., Toride, N., \& Leij, F. (1999). The STANMOD computer software for evaluating solute transport in porous media using analytical solutions of convection-dispersion equation (p. 20). California, USA: U. S. Salinity Laboratory.

Souza, A. P., Prates, H. T., Ferreira, F. A., Reis, E. L., \& Jordão, C. P. (1999). Lixiviação do glyphosate e do imazapyr em solos com diferentes texturas e composição química: II. método analítico. Planta Daninha, 17(2), 245-262. http:/ /dx.doi.org/10.1590/S010083581999000200009 .

Souza, A. S., Leal, J. F. L., Langaro, A. C., Carvalho, G. S., \& Pinho, C. F. (2020). Leaching and carryover for safrinha corn of the herbicides Imazapyr + Imazapic in soil under different water condictions. Revista Caatinga, 33(2), 287-298. http://dx.doi. org/10.1590/1983-21252020v33n202rc.

Souza, M. F. C., Neto, M. D., Marinho, M. I., Saraiva, D. T., Faria, A. T., Silva, A. A., \& Silva, D. V. (2016). Persistence of imidozolinones in soils under a classified system of rice cultivation. Planta Daninha, 34(3), 589-596. http://dx.doi.org/10.1590/s010083582016340300020. 
Spark, K., \& Swift, R. (2002). Effect of soil composition and dissolved organic matter on pesticide sorption. The Science of the Total Environment, 298(1-3), 147-161. PMid:12449335. http:// dx.doi.org/10.1016/S0048-9697(02)00213-9.

Teixeira, P. C., Donagemma, G. K., Fontana, A., \& Teixeira, W. G. (2017). Manual de métodos de análise de solo. Brasília: EMBRAPA. Retrieved in 2021, January 15, from http:/ /www.cse.edu.uy/sites/ www.cse.edu.uy/files/documentos/Liccom_Camejo_2011-07-28.pdf

Ulbrich, A. V., Souza, J. R. P., \& Shaner, D. (2005). Persistence and carryover effect of Imazapic and Imazapyr in Brazilian cropping systems. Weed Technology, 19(4), 986-991. http://dx.doi. org/10.1614/WT-04-208R2.1.

Vanclooster, M., Javaux, M., \& Vanderborght, J. (2006). Solute transport in soil at the core and field scale. In Encyclopedia of bydrological sciences (p. 13). John Wiley.

Veeh, R. H., Inskeep, W. P., Roe, F. L., \& Ferguson, A. H. (1994). Transport of chlorsulfuron through soil columns. Journal of Environmental Quality, 23(3), 542-549. http:/ /dx.doi.org/10.2134/ jeq1994.00472425002300030020x.

Walkley, A., \& Black, I. A. (1934). An examination of the digestion method for determing soil organic matter, and a proposed modification of the chromic acid titration method. Soil Science, 37(1), 29-38. http://dx.doi.org/10.1097/00010694193401000-00003.

Weber, J. B. (1980). Adsorption of Buthidazole, VEL 3510, Tebuthiuron, and Fluridone by organic matter, montmorillonite clay, exchange resins, and a sandy loam soil. Weed Science, 28(5), 478-483. http://dx.doi.org/10.1017/S0043174500061063.

Yong, R., Nakano, M., \& Pusch, R. (2012). Environmental soil and properties behaviour. Florida, USA: CRC Press Taylor \& Francis Group. . http://dx.doi.org/10.1201/b11658.

\section{Authors contributions}

Fernando Xavier de Assis: Conceptualization, Methodology, Formal analysis and investigation, and Writing - original draft preparation.

André Maciel Netto: Conceptualization, Methodology, Writing review and editing, Supervision.

Bruno Toríbio de Lima Xavier: Methodology, Formal analysis and investigation and Writing - review and editing.

Valmir Felix de Lima: Methodology, Formal analysis and investigation and Writing - review and editing.

João Paulo Siqueira da Silva: Methodology, Formal analysis and investigation and Writing - review and editing.

Editor-in-Chief: Adilson Pinheiro

Associated Editor: Edson Cezar Wendland 